\title{
Response of Egyptian Cotton to Mepiquat Chloride Application under Different Plant Spacings
}

\author{
A. H. A. Mahdi \\ Agronomy Department, Faculty of Agriculture, Fayoum \\ University, Fayoum, Egypt.
}

\begin{abstract}
7 HIS STUDY was carried out at Sids Agricultural Research Station, Bani-Swef Governorate, Middle Egypt during the two successive seasons of 2014 and 2015, to study the effect of three plant spacings $(15,20$ and $25 \mathrm{~cm})$ and mepiquat chloride (MC) at three concentrations $(50,100$ and $150 \mathrm{mg} / \mathrm{l})$ on growth, productivity and quality of Egyptian cotton variety Giza 90. The treatments were arranged in field using a split plot in a randomized complete block design with three replications, where plant spacings were the main plots and MC were the sub plots. Results showed that the widest plant spacing $(25 \mathrm{~cm})$ achieved an increase in dry weight/plant, leaf area/plant, number of fruiting branches/plant, earliness percentage, number of open bolls/plant, boll weight, seed cotton yield/feddan, seed index, lint percentage, leaf mineral elements percentage and photosynthetic pigments concentration and seed content of oil and protein. While, plant height, shedding percentage, days to first bud appearance, first open flower and crackle first boll were decreased. On the other hand, node number of the first sympodium and fiber properties were not affected by plant spacings. Spraying MC at the concentration of $150 \mathrm{mg} / \mathrm{l}$ led to increased for each of number of fruiting branches/plant, earliness percentage, number of open bolls/plant, boll weight, seed cotton yield/feddan, seed index, lint percentage, leaf mineral elements percentage and photosynthetic pigments concentration, seed content of oil and protein, micronaire reading, fiber strength and fiber elongation. While, dry weight/plant, leaf area/plant, plant height, shedding percentage, node number of the first sympodium, days to first bud appearance, first open flower and crackle first boll were decreased. On the other hand, fiber length and uniformity ratio were not affected by MC. The interaction between plant spacings and MC significantly affected all studied characters except node number of the first sympodium and fiber properties. From the above results it could be concluded that grown plants on $25 \mathrm{~cm}$ with spraying $\mathrm{MC}$ at the concentration of $150 \mathrm{mg} / \mathrm{l}$ may be the best combination to improve the productivity of Egyptian cotton.
\end{abstract}

Keywords: Egyptian cotton, Plant spacings, Mepiquat chloride.

Egyptian cotton (Gossypium barbadense L.) is the most important commercial fiber crop in Egypt. Cotton occupies a prominent position in Egyptian agriculture. It is the oldest among the commercial fiber crops and is regarded as white gold. Egyptian cotton is preferred around the world because of its long and 
strong fiber which is used as raw material for the textile industry. Cotton is not only the most important fiber crop of the world but, also its seed is the second best source for plant proteins after soybean and the fifth best oil-producing plant after soybean, palm-tree, colza and sunflower (Texier, 1993). Cotton seed meal is the product remaining once the oil has been removed from seeds and can contain up to $41 \%$ protein (Smith, 1995). Cotton seed meal is used in food products for animal feed due to its high protein and energy values. So, it is necessary to increase cotton cultivation area and productivity.

In spite of using high yielding cultivars and the best agronomic practices, the yields of Egyptian cotton have not increased substantially (Sawan et al., 2006). Excess vegetative growth, poor bud development, flower shedding, and growth imbalance between the source and sink are responsible for the unpredictable behavior of the crop. Several approaches have been tried to break this yield plateau and among them application of plant growth regulators (PGRs); particularly mepiquat chloride (MC; 1,1-dimethyl- piperidinium chloride; also known as 'Pix') has received greater attention than the other PGRs in recent years. MC can be used to manage the vegetative development of cotton plants to offset the effect of excessive irrigation or $\mathrm{N}$ by decreasing both overall plant height and length of lateral branches (Boquet \& Coco, 1993). The advantage of MC has been that it gives producers the flexibility to modify plant growth to suit current growing conditions in order to maximize benefits (Landivar et al., 1995). It enhances reproductive organs by allowing plants to direct more energy towards reproductive structures (Wang et al., 1995). Application of MC improved leaf photosynthetic rate and increased lint yield (Zhao \& Oosterhuis, 1999). Nuti et al. (2000) stated that MC is thought to cause a shift in partitioning of photo-assimilates from vegetative to reproductive growth. Redistribution of assimilates between vegetative and reproductive growth may be one means by which yields can be increased.

Nowadays, cotton farmers are faced with the difficult task of selecting management strategies under rising production costs. One alternative method to combat these problems and to optimize profit is growing cotton in optimum plant spacing. Proper spacing of cotton plants can help maximize yield potential. Plant population is directly related to intra- and inter-row spacing of plants, which not only influences crop yield, but also its quality. Plant spacing is important in the establishment of an acceptable plant population for yield enhancement of cotton crop (Bednarz et al., 2005). Maximum yield potential of cotton can be obtained by adopting the optimum plant density, fertilizer and better agronomic practices (Shekar et al., 2015). Among different agronomic practices, plant spacing plays a key role in maintaining optimum plant population of cotton with improvement in its yield and quality (Nawaz et al., 2016).

The main objective of this study was to investigate the interactive effects of different plant spacings and mepiquat chloride application on growth, earliness, yield and its components, chemical characters and fiber properties of Egyptian cotton.

Egypt. J. Agron. 38, No. 1 (2016) 


\section{Materials and Methods}

Plant material, growing conditions, experimental design and treatments

This investigation was carried out at the Sids Agricultural Research Station, Bani-Swef Governorate, Middle Egypt during the two successive seasons of 2014 and 2015. Seeds of Giza 90 were sown in hills within rows on 1 Apr. 2014 and 3 Apr. 2015. The treatments were arranged in field using a split plot in a randomized complete block design with three replications, where three plant spacings $(15,20$ and $25 \mathrm{~cm})$ were the main plots and mepiquat chloride at the three concentrations $(50,100$ and $150 \mathrm{mg} / \mathrm{l})$ were the sub plots. Sub plots consisted of 5 ridges $60 \mathrm{~cm}$ apart and 3.5 meters long $\left(10.5 \mathrm{~m}^{2}\right)$. Thinning was done before the first irrigation to produce two plants per hill. Mechanical analysis (Kilmer \& Alexander, 1940) and chemical characteristics (Chapman \& Pratt, 1961) for soil in both seasons are illustrated in Table .

TABLE 1. Mechanical and chemical analysis of soil sample.

\begin{tabular}{|l|c|c|}
\hline \multicolumn{1}{|c|}{ Properties } & $\mathbf{2 0 1 4}$ & $\mathbf{2 0 1 5}$ \\
\hline Mechanical analysis: & & 55.29 \\
\hline Clay (\%) & 53.17 & 17.38 \\
\hline Sand (\%) & 17.29 & 27.33 \\
\hline Silt $(\%)$ & 29.54 & Clay \\
\hline Soil texture & Clay & \\
\hline Chemical analysis: & & 1.81 \\
\hline Organic matter $(\%)$ & 1.73 & 2.93 \\
\hline CaCO $(\%)$ & 2.71 & 8.09 \\
\hline PH (at a soil: water (w/v) ratio of $1: 2.5)$ & 8.11 & 0.83 \\
\hline ECe $\left(\mathrm{dS}\right.$ m $^{-1} ;$ soil-paste extract) & 0.85 & 30.00 \\
\hline $\mathrm{N}(\mathrm{ppm})$ & 31.00 & 16.00 \\
\hline $\mathrm{P}(\mathrm{ppm})$ & 15.50 & 223 \\
\hline $\mathrm{K}(\mathrm{ppm})$ & 211 & 3.93 \\
\hline $\mathrm{Fe}(\mathrm{ppm})$ & 3.79 & 1.53 \\
\hline $\mathrm{Mn}(\mathrm{ppm})$ & 1.51 & 0.73 \\
\hline $\mathrm{Zn}(\mathrm{ppm})$ & 0.77 & 0.13 \\
\hline $\mathrm{Cu}(\mathrm{ppm})$ & 0.15 & \\
\hline
\end{tabular}

During soil preparation and plant growth, the soil was supplemented with the full dose of NPK fertilizer according to the recommendations of the Ministry of Agriculture and Land Reclamation. Phosphorus fertilizer as superphosphate $\left(15.5 \% \mathrm{P}_{2} \mathrm{O}_{5}\right)$ at the levels of $30 \mathrm{~kg} \mathrm{P}_{2} \mathrm{O}_{5} /$ feddan was incorporated during seed bed preparation. Nitrogen fertilizer in the form of ammonium nitrate $(33.5 \% \mathrm{~N})$ at the rate of $60 \mathrm{~kg} \mathrm{~N} /$ faddan was applied in two equal doses, immediately before the first and the second irrigations. Potassium fertilizer was applied in the form of potassium sulfate $\left(48 \% \mathrm{~K}_{2} \mathrm{O}\right)$ at the level of $48 \mathrm{~kg} \mathrm{~K}_{2} \mathrm{O} /$ feddan was sidedressed in one dose before the second irrigation. All other recommended agricultural practices were followed as recommended by the Ministry of Agriculture and Land Reclamation. 


\section{Field sampling and data collection}

Growth attributes

The samples were taken at random from each experimental plot at 120 days after sowing to determine dry weight/plant $(\mathrm{g})$ and leaf area/plant $\left(\mathrm{dm}^{2}\right)$ as calculated by the disc method according to Johnson (1967) by the following formula: LA/P $\left(\mathrm{dm}^{2}\right)=$ Leaf dry weight/plant $\mathrm{x}$ Discs area/Disc dry weight. Plant height $(\mathrm{cm})$ and number of fruiting branches/plant were counted from ten sampled plants at harvest and then the average per plant was calculated. Shedding percentage was calculated during the flowering and fruiting periods by the following formula :

Total No. of flowers/plant - Total No.of open bolls/plant

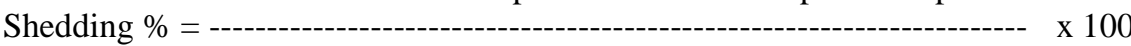

Total No. of flowers/plant

\section{Earliness parameters}

Node number of the first sympodium, days to first bud appearance, first open flower and crackle first boll were recorded. In addition earliness percentage was calculated according to the following equation :

$$
\text { Earliness } \%=\frac{\text { Seed cotton yield of the first pick }(\mathrm{kg})}{\text { Total seed cotton yield }(\mathrm{kg})}
$$

Yield and its components

At harvest, ten guarded plants from each experimental unit were randomly chosen from the central ridge to determine number of open bolls/plant and boll weight $(\mathrm{g})$. Total seed cotton yield of each plot in kilograms (including 10 plant subsamples) was then transformed to kentars per feddan and ginned to determine the seed index (g). Lint percentage was calculated according to the following equation :

$$
\text { Lint } \%=\frac{\text { Weight of lint cotton }}{\text { Weight of seed cotton }}
$$

Chemical analysis

Samples of the upper fourth leaves were collected at 15 days after the spraying $\mathrm{MC}$ to determine leaf mineral elements percentage, i.e. total nitrogen as described by the method of Horneck \& Miller (1998), phosphorus by the method of Sandell (1950), potassium by the method of Horneck \& Hanson (1998) and (Ca \& Mg) by the AOAC (1990) method. Leaf photosynthetic pigments concentration (chlorophyll $\mathrm{a}, \mathrm{b}$ and carotenoids in $\mathrm{mg} / \mathrm{g} \mathrm{FW}$ ) were estimated following the procedure given by Lichtenthaler (1987). Leaf samples $(0.5 \mathrm{~g})$ were homogenized in $50 \mathrm{ml} 90 \%(\mathrm{v} / \mathrm{v})$ acetone and centrifuged at $10,000 \times g$ for $10 \mathrm{~min}$. The absorbance of each acetone extract was measured at 665, 649, and $440 \mathrm{~nm}$ using a UV-160A UV-visible spectrophotometer (Shimadzu, Kyoto, Japan). Oil and protein content were determined in the seeds by the methods described by AOAC (1990).

Egypt. J. Agron. 38, No. 1 (2016) 


\section{Fiber properties}

The measurements of fiber properties were carried out in the Cotton Technology Research Division, Cotton Research Institute, Giza, Egypt. Fiber tests were conducted at a relative humidity of $65 \pm 2 \%$ and a temperature of $20 \pm$ $1{ }^{\circ} \mathrm{C}$ to determine fiber length in terms of 2.5 span length $(\mathrm{mm})$ and uniformity ratio as measured by a digital fibrograph (ASTM, 1998a). Micronaire reading, including combined measure of fiber fineness and maturity was measured by a micronaire instrument (ASTM, 1998b). Fiber strength in gram/tex was measured by stelometer at 1/8 inch gauge length and fiber elongation\% (ASTM, 1998c).

Statistical analysis

Data were statistically analyzed by using Fisher's analysis of variance techniques and differences among treatment means were compared using least significant difference test at 5\% probability level (Steel et al., 1997).

\section{Results and Discussion}

The obtained results will be discussed under the following topics; growth, earliness, seed and lint yields besides chemical and fiber properties as affected by different plant spacings and mepiquat chloride.

\section{Growth attributes}

Effect of plant spacings

Data presented in Table 2 indicate that plant spacings significantly affected all growth attributes during the two seasons. Dry weight/plant, leaf area/plant and number of fruiting branches/plant tended to increase as plant spacings were increased from 15 up to $25 \mathrm{~cm}$. These increases might be due to that expanding hill spacing, plants would have better opportunity to produce more metabolite contents. This would in turn have a positive effect on these characters. On the other hand, plant height at harvest and shedding percentage tended to decrease as plant spacings were increased from 15 up to $25 \mathrm{~cm}$. These results are in agreement with those obtained by El-Hindi et al. (2006), Ali et al. (2009) and Awan et al. (2011).

\section{Effect of mepiquat chloride}

Data in Table 2 reveale that all growth attributes under study were significantly affected by application of different concentrations of mepiquat chloride in the two seasons. Spraying MC at the concentration of $150 \mathrm{mg} / \mathrm{l}$ led to significantly reduced dry weight/plant, leaf area/plant, plant height at harvest and shedding percentage as compared to other concentrations. These reductions due to MC application that could be explained on the basis that MC partially inhibit one of the enzymes that are involved in gibberellic acid biosynthesis which is an important plant hormone for all elongation. While, the number of fruiting branches/plant in the same treatment significantly increased. Similar results were obtained by Ali \& El-Sayed (2001) and Elayan et al. (2013). 
TABLE 2. The effect of plant spacings and mepiquat chloride on growth attributes during 2014 and 2015 seasons.

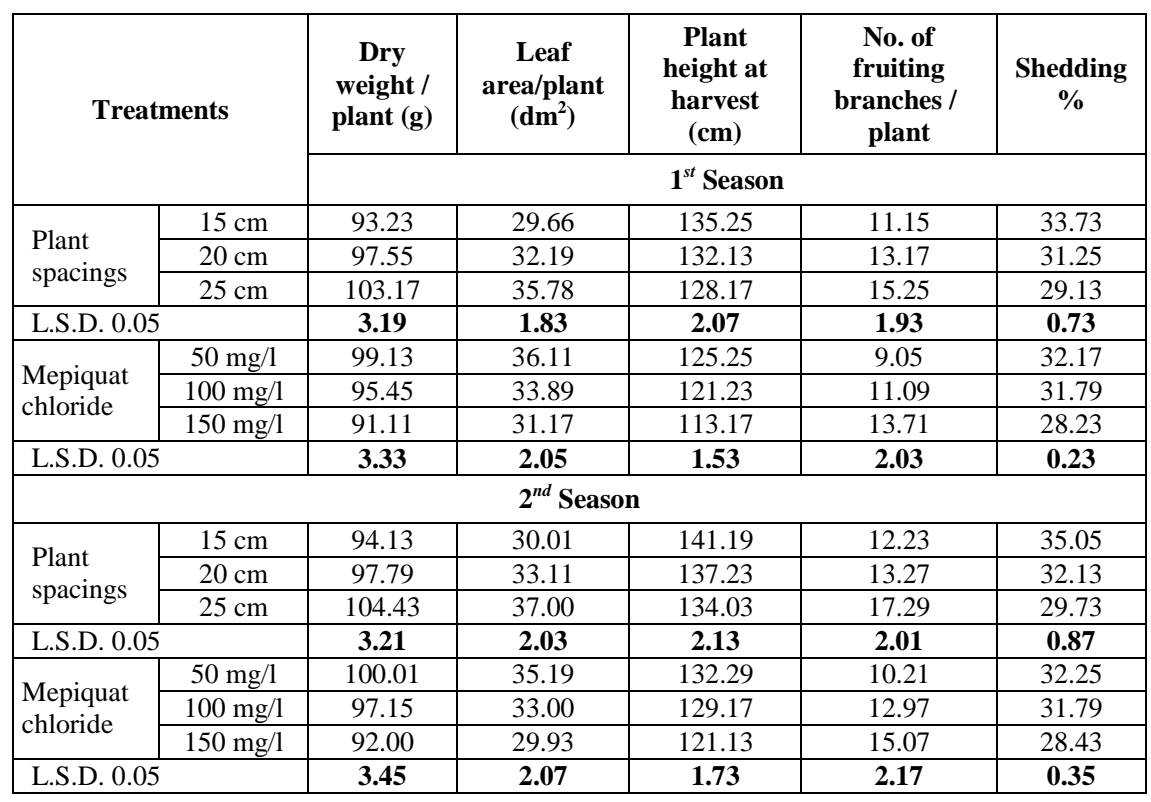

\section{Effect of the interaction}

The interaction effect between plant spacings and mepiquat chloride had a significant effect on growth attributes in both seasons as presented in Table 3. The widest spacing between plants $(25 \mathrm{~cm})$ with high concentration MC (150 $\mathrm{mg} / \mathrm{l}$ ) achieved a decrease in dry weight/plant, leaf area/plant, plant height at harvest and shedding percentage, whereas number of fruiting branches/plant was increased. The same results were obtained by Nichols et al. (2003).

\section{Earliness parameters}

Effect of plant spacings

Results recorded in Table 4 show the effect of plant spacings on earliness parameters during the 2014 and 2015 seasons. Plant spacings had no significant effect on node number of the first sympodium. Extensive plant spacing $(25 \mathrm{~cm})$ gave better earliness, indicated by low values for the days to first bud (35.11 and 37.11), first flower (83.25 and 83.73) and first boll (131.03 and 131.73) and high earliness percentage (65.89 and $67.00 \%)$ in the two growing study respectively, as compared to the dense spacings. These results might be due to low plant spacings tending to furnish less competition between plants for light intensity as well as nutrients and moisture, these conditions helped to produce plants with vigorous vegetative growth and enhancing the initiation of first flower and this in turn the first boll early opening. These results are in harmony with those obtained by ElShahawy et al. (1994), Makram et al. (1994) and Abdel-Malak et al. (1996). 
RESPONSE OF EGYPTIAN COTTON TO MEPIQUAT CHLORIDE...

TABLE 3. The effect of interaction between plant spacings and mepiquat chloride on growth attributes during 2014 and 2015 seasons.

\begin{tabular}{|c|c|c|c|c|c|c|}
\hline \multicolumn{2}{|c|}{ Treatments } & \multirow{2}{*}{$\begin{array}{c}\text { Dry } \\
\text { weight / } \\
\text { plant (g) }\end{array}$} & \multirow{2}{*}{$\begin{array}{c}\text { Leaf } \\
\text { area/plant } \\
\left(\mathbf{d m}^{2}\right)\end{array}$} & \multirow{2}{*}{ 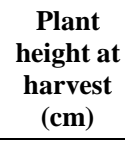 } & \multirow{2}{*}{$\begin{array}{c}\text { No. of } \\
\text { fruiting } \\
\text { branches / } \\
\text { plant }\end{array}$} & \multirow{2}{*}{$\begin{array}{c}\text { Shedding } \\
\%\end{array}$} \\
\hline \multirow{2}{*}{$\begin{array}{l}\text { Plant } \\
\text { spacings }\end{array}$} & \multirow{2}{*}{$\begin{array}{l}\text { Mepiquat } \\
\text { chloride }\end{array}$} & & & & & \\
\hline & & \multicolumn{5}{|c|}{$\mathbf{1}^{s t}$ Season } \\
\hline \multirow{3}{*}{$15 \mathrm{~cm}$} & $50 \mathrm{mg} / 1$ & 95.00 & 32.01 & 133.27 & 9.21 & 34.11 \\
\hline & $100 \mathrm{mg} / \mathrm{l}$ & 93.89 & 29.00 & 127.13 & 10.23 & 33.17 \\
\hline & $150 \mathrm{mg} / \mathrm{l}$ & 91.17 & 27.16 & 121.19 & 11.05 & 31.67 \\
\hline \multirow{3}{*}{$20 \mathrm{~cm}$} & $50 \mathrm{mg} / \mathrm{l}$ & 96.51 & 33.19 & 126.07 & 11.23 & 32.19 \\
\hline & $100 \mathrm{mg} / \mathrm{l}$ & 94.03 & 30.00 & 123.15 & 12.75 & 29.15 \\
\hline & $150 \mathrm{mg} / \mathrm{l}$ & 92.23 & 27.51 & 116.23 & 14.01 & 28.01 \\
\hline \multirow{3}{*}{$25 \mathrm{~cm}$} & $50 \mathrm{mg} / \mathrm{l}$ & 97.71 & 35.01 & 117.29 & 11.79 & 29.79 \\
\hline & $100 \mathrm{mg} / \mathrm{l}$ & 95.19 & 31.55 & 111.21 & 13.03 & 28.03 \\
\hline & $150 \mathrm{mg} / \mathrm{l}$ & 93.00 & 28.00 & 104.61 & 15.13 & 27.00 \\
\hline \multicolumn{2}{|c|}{ L.S.D. 0.05} & 1.79 & 4.13 & 2.85 & 2.25 & 1.53 \\
\hline \multicolumn{7}{|c|}{$2^{\text {nd }}$ Season } \\
\hline \multirow{3}{*}{$15 \mathrm{~cm}$} & $50 \mathrm{mg} / \mathrm{l}$ & 97.00 & 33.19 & 144.21 & 9.45 & 36.19 \\
\hline & $100 \mathrm{mg} / \mathrm{l}$ & 95.13 & 31.00 & 132.41 & 10.23 & 34.09 \\
\hline & $150 \mathrm{mg} / \mathrm{l}$ & 93.11 & 27.89 & 128.33 & 11.15 & 32.11 \\
\hline \multirow{3}{*}{$20 \mathrm{~cm}$} & $50 \mathrm{mg} / \mathrm{l}$ & 99.01 & 35.17 & 131.31 & 11.29 & 33.79 \\
\hline & $100 \mathrm{mg} / \mathrm{l}$ & 97.11 & 32.00 & 128.11 & 12.88 & 30.13 \\
\hline & $150 \mathrm{mg} / \mathrm{l}$ & 95.00 & 29.01 & 119.22 & 14.07 & 28.97 \\
\hline \multirow{3}{*}{$25 \mathrm{~cm}$} & $50 \mathrm{mg} / \mathrm{l}$ & 100.01 & 36.11 & 121.20 & 12.03 & 31.00 \\
\hline & $100 \mathrm{mg} / \mathrm{l}$ & 98.00 & 33.89 & 114.00 & 14.09 & 29.01 \\
\hline & $150 \mathrm{mg} / \mathrm{l}$ & 96.98 & 30.03 & 108.25 & 16.78 & 27.51 \\
\hline \multicolumn{2}{|c|}{ L.S.D. 0.05} & 2.11 & 4.25 & 3.03 & 2.45 & 1.65 \\
\hline
\end{tabular}

TABLE 4. The effect of plant spacings and mepiquat chloride on earliness parameters during 2014 and 2015 seasons.

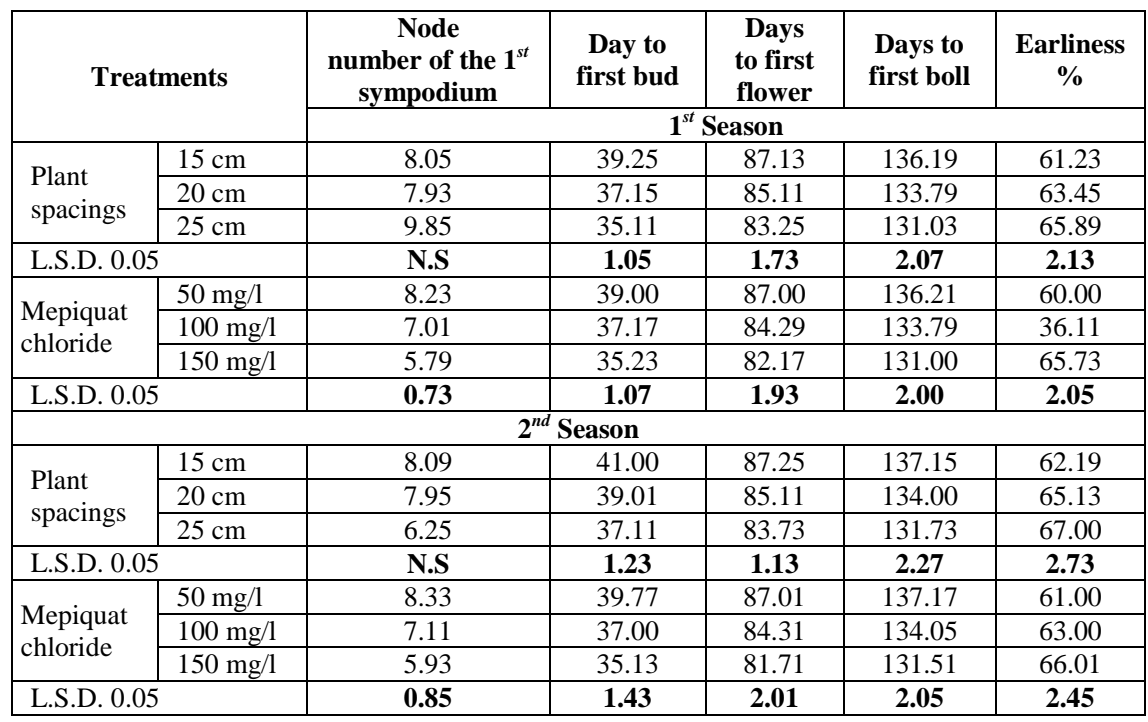


Effect of mepiquat chloride

From Table 4 it is evident that mepiquat chloride concentrations had a significant effect on all earliness parameters during the two seasons. Results indicated that applying MC at $150 \mathrm{mg} / \mathrm{l}$ gave lower node number of the first sympodium (5.79 and 6.25) and enhanced maturation as indicated by reducing days to first bud (35.23 and 35.13), first flower (82.17 and 81.71), consequently first boll (131.00 and 131.51) and increasing earliness percentage (65.73 and $66.01 \%$ ) in first and second seasons respectively, as compared to rates at 50 or $100 \mathrm{mg} / \mathrm{l}$. These results could be ascribed on the basis that as MC reduces plant growth it causes a more open canopy which allows better light penetration and aeration and therefore a more favorable microclimate for boll maturation. Similar results were obtained by El-Sayed (2006) and Emara et al. (2009).

\section{Effect of the interaction}

The interaction between of the two studied treatments had a significant effect on all earliness parameters except node number of the first sympodium in the two growing seasons. Data in Table 5 reveal that the lowest values of days to first bud, first flower and first boll were obtained from plants sown on $25 \mathrm{~cm}$ between hills with using MC at $150 \mathrm{mg} / \mathrm{l}$, while gave the highest values of earliness percentage. The obtained results may be in line with those presented by Iqbal et al. (2007).

TABLE 5. The effect of interaction between plant spacings and mepiquat chloride on earliness parameters during 2014 and 2015 seasons.

\begin{tabular}{|c|c|c|c|c|c|c|}
\hline \multicolumn{2}{|c|}{ Treatments } & \multirow{2}{*}{$\begin{array}{c}\text { Node } \\
\text { number of the } 1^{s t} \\
\text { sympodium }\end{array}$} & \multirow{2}{*}{$\begin{array}{l}\text { Day to } \\
\text { first bud }\end{array}$} & \multirow{2}{*}{$\begin{array}{l}\text { Days } \\
\text { to first } \\
\text { flower }\end{array}$} & \multirow{2}{*}{$\begin{array}{l}\text { Days to } \\
\text { first boll }\end{array}$} & \multirow{2}{*}{$\begin{array}{c}\text { Earliness } \\
\%\end{array}$} \\
\hline \multirow{2}{*}{$\begin{array}{l}\text { Plant } \\
\text { spacings }\end{array}$} & \multirow{2}{*}{$\begin{array}{l}\text { Mepiquat } \\
\text { chloride }\end{array}$} & & & & & \\
\hline & & \multicolumn{5}{|c|}{$1^{s t}$ Season } \\
\hline \multirow{3}{*}{$15 \mathrm{~cm}$} & $50 \mathrm{mg} / \mathrm{l}$ & 8.33 & 39.89 & 88.23 & 135.91 & 60.00 \\
\hline & $100 \mathrm{mg} / 1$ & 8.03 & 37.00 & 86.17 & 133.21 & 62.66 \\
\hline & $150 \mathrm{mg} / 1$ & 7.45 & 34.19 & 84.17 & 131.27 & 63.00 \\
\hline \multirow{3}{*}{$20 \mathrm{~cm}$} & $50 \mathrm{mg} / \mathrm{l}$ & 8.11 & 38.11 & 86.93 & 133.79 & 61.13 \\
\hline & $100 \mathrm{mg} / \mathrm{l}$ & 7.79 & 36.00 & 84.13 & 132.01 & 63.88 \\
\hline & $150 \mathrm{mg} / \mathrm{l}$ & 7.05 & 33.89 & 82.19 & 130.29 & 65.77 \\
\hline \multirow{3}{*}{$25 \mathrm{~cm}$} & $50 \mathrm{mg} / \mathrm{l}$ & 8.00 & 37.11 & 84.79 & 132.17 & 63.00 \\
\hline & $100 \mathrm{mg} / \mathrm{l}$ & 7.25 & 35.55 & 82.01 & 130.79 & 65.11 \\
\hline & $150 \mathrm{mg} / \mathrm{l}$ & 6.53 & 33.00 & 80.00 & 129.03 & 67.23 \\
\hline \multicolumn{2}{|c|}{ L.S.D. 0.05} & N.S & 3.11 & 3.71 & 3.21 & 2.17 \\
\hline \multicolumn{7}{|c|}{$2^{\text {nd }}$ Season } \\
\hline \multirow{3}{*}{$15 \mathrm{~cm}$} & $50 \mathrm{mg} / \mathrm{l}$ & 8.39 & 40.03 & 88.34 & 135.99 & 59.79 \\
\hline & $100 \mathrm{mg} / \mathrm{l}$ & 8.09 & 39.00 & 86.17 & 134.01 & 61.00 \\
\hline & $150 \mathrm{mg} / \mathrm{l}$ & 7.56 & 36.99 & 85.01 & 132.00 & 63.00 \\
\hline \multirow{3}{*}{$20 \mathrm{~cm}$} & $50 \mathrm{mg} / \mathrm{l}$ & 8.11 & 39.00 & 87.09 & 133.79 & 60.19 \\
\hline & $100 \mathrm{mg} / \mathrm{l}$ & 7.81 & 37.44 & 84.79 & 131.89 & 63.11 \\
\hline & $150 \mathrm{mg} / \mathrm{l}$ & 7.05 & 35.00 & 83.01 & 130.13 & 65.00 \\
\hline \multirow{3}{*}{$25 \mathrm{~cm}$} & $50 \mathrm{mg} / \mathrm{l}$ & 8.00 & 37.22 & 84.93 & 133.00 & 62.18 \\
\hline & $100 \mathrm{mg} / \mathrm{l}$ & 7.31 & 35.00 & 82.01 & 131.79 & 64.00 \\
\hline & $150 \mathrm{mg} / \mathrm{l}$ & 6.55 & 32.23 & 80.03 & 129.11 & 67.03 \\
\hline \multicolumn{2}{|c|}{ L.S.D. 0.05} & N.S & 3.23 & 3.83 & 3.45 & 2.15 \\
\hline
\end{tabular}

Egypt. J. Agron. 38, No. 1 (2016) 


\section{Yield and its components}

Effect of plant spacings

It is clear from Table 6 that yield and its components (i.e. number of open bolls/plant, boll weight, seed cotton yield/feddan, seed index and lint percentage) were significantly increased in favour of widest spacing $(25 \mathrm{~cm})$ in both seasons. The averages of these components were 17.93, $2.93 \mathrm{~g}, 9.23 \mathrm{kentar}, 9.83 \mathrm{~g}$, and $35.19 \%$ in $1^{\text {st }}$ season, respectively. The corresponding values were $18.13,2.97 \mathrm{~g}$, 9.73 kentar, $10.01 \mathrm{~g}$ and $36.00 \%$ in $2^{\text {nd }}$ season in respective order. This increase may be due a more canopy that allows better light and air penetration and therefore increasing metabolites in plants tissues. Similar findings were obtained by Sarkar \& Malik (2004) and Somro et al. (2005) reported that the wider and optimum plant spacing enables plants to capture solar radiation which in turn increase the photosynthesis of the plants and ultimately yield and its components in cotton plants.

TABLE 6. The effect of plant spacings and mepiquat chloride on yield and its components during 2014 and 2015 seasons.

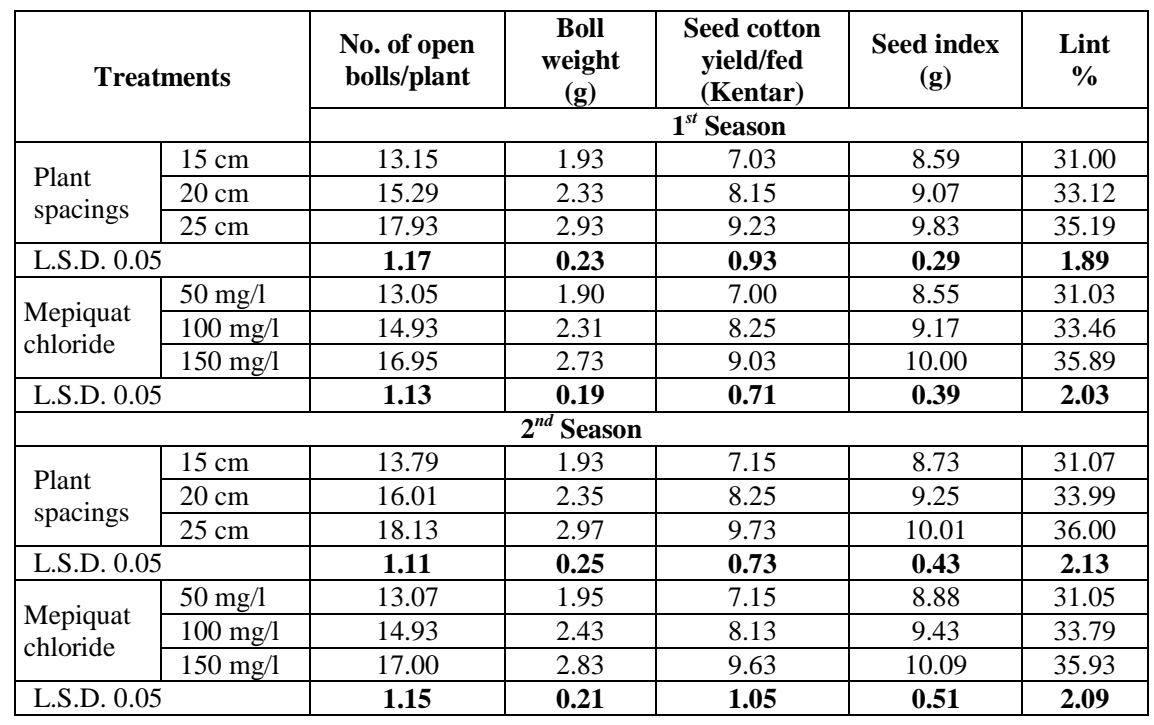

Effect of mepiquat chloride

As shown in Table 6 there was significant effect of mepiquat chloride on yield and its components during the two seasons. The highest values of the number of open bolls/plant, boll weight, seed cotton yield/feddan, seed index and lint percentage were obtained by use $150 \mathrm{mg} / \mathrm{l}$. The average values were 16.95, $2.73 \mathrm{~g}, 9.03 \mathrm{Kentar}, 10.00 \mathrm{~g}$ and $35.89 \%$, in the first season, respectively. The same trend was obtained in the second season. The above results could be ascribed to the fact that $\mathrm{MC}$ acts as a reducer to abscisic acid and ethylene hormones which in turn increases boll retention and consequently more open and heavier bolls. These results are in agreement with those obtained by El-Shahawy (1999) and Ahmed et al. (2014). 
Effect of the interaction

The interaction of plant spacings $\mathrm{x}$ mepiquat chloride had a significant effect on yield and its components in both seasons (Table 7). The highest values of the number of open bolls/plant, boll weight, seed cotton yield/feddan, seed index and lint percentage were obtained from combination $(25 \mathrm{~cm} \times 150 \mathrm{mg} / \mathrm{l})$. These results support those reported by Nichols et al. (2003).

TABLE 7. The effect of interaction between plant spacings and mepiquat chloride on yield and its components during 2014 and 2015 seasons.

\begin{tabular}{|c|c|c|c|c|c|c|}
\hline \multicolumn{2}{|c|}{ Treatments } & \multirow{2}{*}{$\begin{array}{c}\text { No. of } \\
\text { open } \\
\text { bolls/plant }\end{array}$} & \multirow{2}{*}{$\begin{array}{c}\text { Boll } \\
\text { weight } \\
\text { (g) }\end{array}$} & \multirow{2}{*}{$\begin{array}{c}\text { Seed cotton } \\
\text { yield/fed } \\
\text { (Kentar) }\end{array}$} & \multirow{2}{*}{$\begin{array}{c}\text { Seed } \\
\text { index } \\
(\mathrm{g})\end{array}$} & \multirow{2}{*}{$\underset{\%}{\operatorname{Lint}}$} \\
\hline \multirow{2}{*}{$\begin{array}{c}\text { Plant } \\
\text { spacings }\end{array}$} & \multirow{2}{*}{$\begin{array}{l}\text { Mepiquat } \\
\text { chloride }\end{array}$} & & & & & \\
\hline & & & & $\mathbf{1}^{\text {st }}$ Season & & \\
\hline \multirow{3}{*}{$15 \mathrm{~cm}$} & $50 \mathrm{mg} / 1$ & 11.23 & 1.79 & 7.33 & 7.93 & 30.11 \\
\hline & $100 \mathrm{mg} / \mathrm{l}$ & 13.07 & 1.97 & 8.00 & 8.55 & 32.03 \\
\hline & $150 \mathrm{mg} / 1$ & 15.11 & 2.13 & 8.75 & 9.11 & 34.00 \\
\hline \multirow{3}{*}{$20 \mathrm{~cm}$} & $50 \mathrm{mg} / \mathrm{l}$ & 13.17 & 1.93 & 7.63 & 8.15 & 31.05 \\
\hline & $100 \mathrm{mg} / \mathrm{l}$ & 15.25 & 2.11 & 8.11 & 8.97 & 32.89 \\
\hline & $150 \mathrm{mg} / \mathrm{l}$ & 17.00 & 2.43 & 9.03 & 9.61 & 34.03 \\
\hline \multirow{3}{*}{$25 \mathrm{~cm}$} & $50 \mathrm{mg} / \mathrm{l}$ & 14.89 & 2.03 & 7.95 & 8.73 & 32.00 \\
\hline & $100 \mathrm{mg} / \mathrm{l}$ & 17.01 & 2.43 & 8.23 & 9.43 & 34.09 \\
\hline & $150 \mathrm{mg} / \mathrm{l}$ & 18.97 & 2.97 & 9.11 & 10.03 & 35.63 \\
\hline \multicolumn{2}{|c|}{ L.S.D. 0.05} & 2.13 & 0.89 & 1.25 & 0.75 & 2.11 \\
\hline \multicolumn{7}{|c|}{$2^{\text {nd }}$ Season } \\
\hline \multirow{3}{*}{$15 \mathrm{~cm}$} & $50 \mathrm{mg} / \mathrm{l}$ & 11.08 & 1.64 & 7.18 & 7.78 & 29.96 \\
\hline & $100 \mathrm{mg} / \mathrm{l}$ & 12.92 & 1.82 & 7.85 & 8.40 & 31.88 \\
\hline & $150 \mathrm{mg} / \mathrm{l}$ & 14.96 & 1.98 & 8.60 & 8.96 & 33.85 \\
\hline \multirow{3}{*}{$20 \mathrm{~cm}$} & $50 \mathrm{mg} / \mathrm{l}$ & 13.02 & 1.78 & 7.51 & 8.00 & 30.90 \\
\hline & $100 \mathrm{mg} / \mathrm{l}$ & 15.10 & 1.96 & 7.96 & 8.82 & 32.74 \\
\hline & $150 \mathrm{mg} / \mathrm{l}$ & 16.85 & 2.28 & 8.88 & 9.46 & 33.88 \\
\hline \multirow{3}{*}{$25 \mathrm{~cm}$} & $50 \mathrm{mg} / \mathrm{l}$ & 14.74 & 1.88 & 7.84 & 8.58 & 31.85 \\
\hline & $100 \mathrm{mg} / \mathrm{l}$ & 16.86 & 2.28 & 8.08 & 9.28 & 33.94 \\
\hline & $150 \mathrm{mg} / \mathrm{l}$ & 18.82 & 2.82 & 9.03 & 9.88 & 35.48 \\
\hline \multicolumn{2}{|c|}{ L.S.D. 0.05} & 2.09 & 0.83 & 1.21 & 0.73 & 2.07 \\
\hline
\end{tabular}

Chemical characters

Effect of plant spacings

All chemical characters were significantly affected by plant spacings during the two seasons (Tables 8 and 9). The maximum values of mineral elements (i.e., $\mathrm{N}, \mathrm{P}$, $\mathrm{K}, \mathrm{Mg}$ and $\mathrm{Ca}$ ), photosynthetic pigments (i.e., chlorophyll $\mathrm{a}, \mathrm{b}$ and carotenoids), oil and protein content were obtained from the widest spacing $(25 \mathrm{~cm})$. These results are in line with those reported by Jat \& Nanwal (2013).

Effect of mepiquat chloride

Data in Tables 8 and 9 indicate significant effect of mepiquat chloride on all chemical characters during the two seasons. $\mathrm{MC}$ at $150 \mathrm{mg} / \mathrm{l}$ increased leaf mineral elements percentage (i.e. $\mathrm{N}, \mathrm{P}, \mathrm{K}, \mathrm{Mg}$ and $\mathrm{Ca}$ ) coupled with increased leaf photosynthetic pigments concentration (i.e. chlorophyll a, b and carotenoids), in addition to increased seed content of oil and protein. This result is in full agreement with that obtained by Mehasen et al. (2012).

Egypt. J. Agron. 38, No. 1 (2016) 
TABLE 8. The effect of plant spacings and mepiquat chloride on leaf mineral elements percentage during 2014 and 2015 seasons.

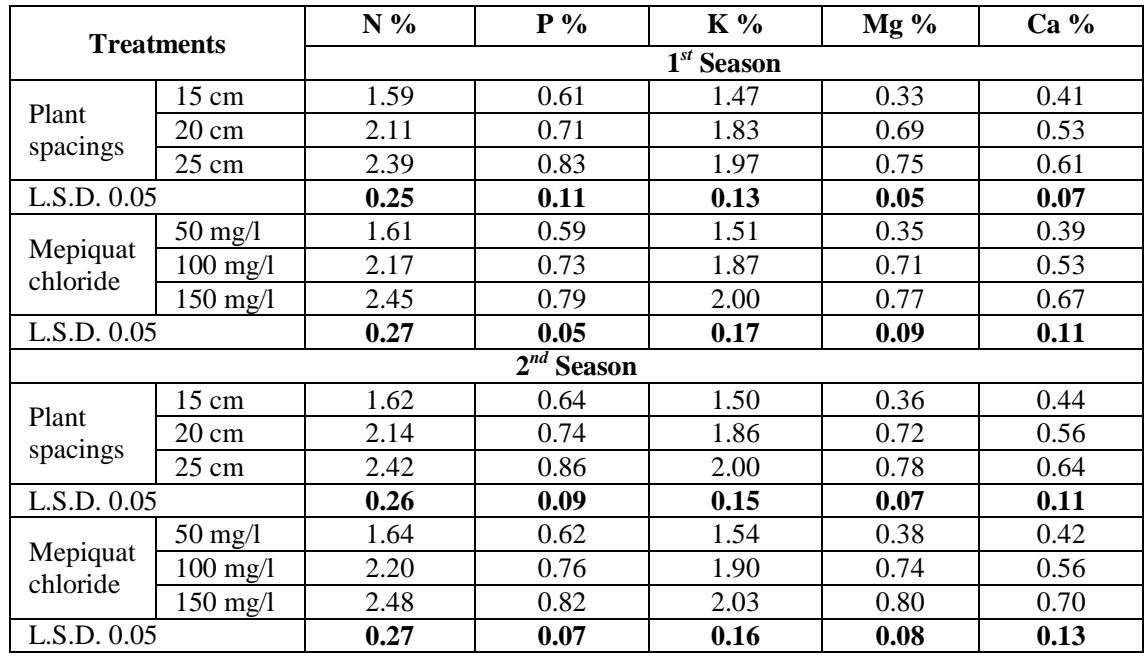

TABLE 9. The effect of plant spacings and mepiquat chloride on leaf photosynthetic pigments concentration $(\mathrm{mg} / \mathrm{g} \mathrm{FW})$ and seed chemical composition during 2014 and 2015 seasons.

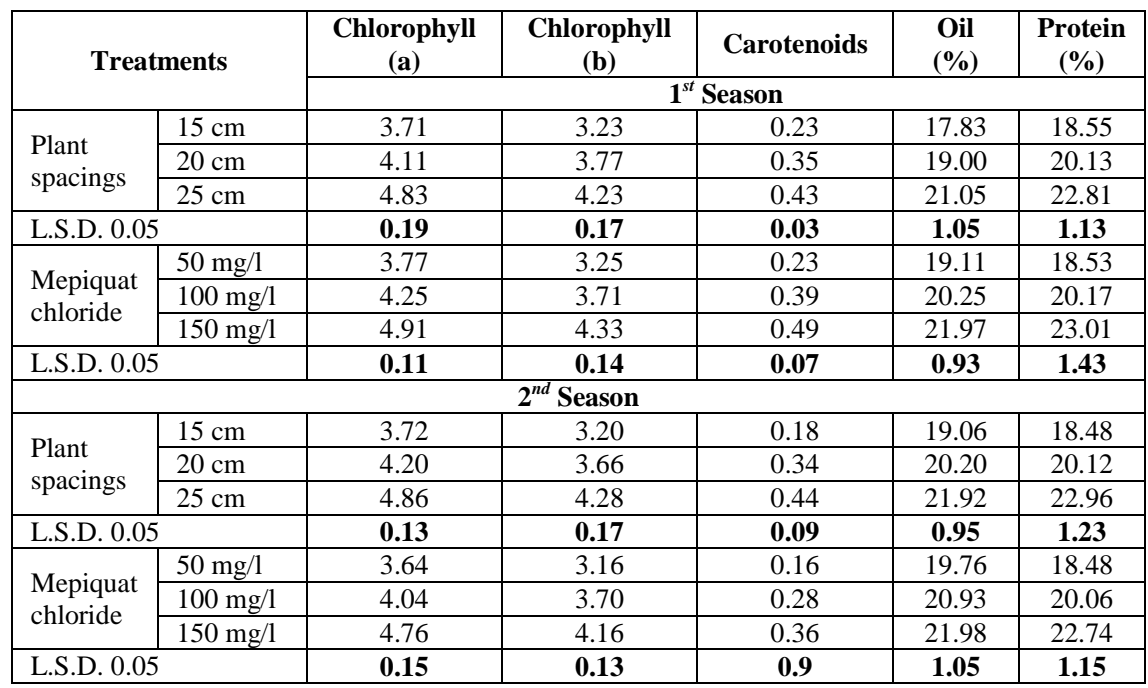

Effect of the interaction

The effect of interaction between plant spacings and mepiquat chloride had a significant effect on all of the studied chemical characters in the both seasons as presented in Tables 10 and 11 . The widest spacing between plants $(25 \mathrm{~cm})$ with high concentration MC $(150 \mathrm{mg} / \mathrm{l})$ exhibited increase in $\mathrm{N}, \mathrm{P}, \mathrm{K}, \mathrm{Mg}, \mathrm{Ca} \%$, chlorophyll a, $\mathrm{b}$, carotenoids, oil and protein content as compared to the other treatments. These results are in agreement with those reported by Shekar et al. (2015). 
TABLE 10. The effect of interaction between plant spacings and mepiquat chloride on leaf mineral elements percentage during 2014 and 2015 seasons.

\begin{tabular}{|c|c|c|c|c|c|c|}
\hline \multicolumn{2}{|c|}{ Treatments } & \multirow{2}{*}{ N \% } & \multirow{2}{*}{ P \% } & \multirow{2}{*}{$\mathbf{K} \%$} & \multirow{2}{*}{$\operatorname{Mg} \%$} & \multirow{2}{*}{ Са \% } \\
\hline \multirow{2}{*}{$\begin{array}{c}\text { Plant } \\
\text { spacings }\end{array}$} & \multirow{2}{*}{\begin{tabular}{|c|}
$\begin{array}{c}\text { Mepiquat } \\
\text { chloride }\end{array}$ \\
\end{tabular}} & & & & & \\
\hline & & \multicolumn{5}{|c|}{$1^{s t}$ Season } \\
\hline \multirow{3}{*}{$15 \mathrm{~cm}$} & $50 \mathrm{mg} / 1$ & 1.51 & 0.59 & 1.45 & 0.31 & 0.39 \\
\hline & $100 \mathrm{mg} / \mathrm{l}$ & 1.83 & 0.63 & 1.51 & 0.39 & 0.45 \\
\hline & $150 \mathrm{mg} / \mathrm{l}$ & 1.95 & 0.71 & 1.63 & 0.47 & 0.51 \\
\hline \multirow{3}{*}{$20 \mathrm{~cm}$} & $50 \mathrm{mg} / \mathrm{l}$ & 1.69 & 0.63 & 1.51 & 0.35 & 0.43 \\
\hline & $100 \mathrm{mg} / 1$ & 1.79 & 0.71 & 1.64 & 0.49 & 0.55 \\
\hline & $150 \mathrm{mg} / \mathrm{l}$ & 1.99 & 0.82 & 1.73 & 0.63 & 0.61 \\
\hline \multirow{3}{*}{$25 \mathrm{~cm}$} & $50 \mathrm{mg} / 1$ & 1.75 & 0.69 & 1.69 & 0.49 & 0.49 \\
\hline & $100 \mathrm{mg} / \mathrm{l}$ & 1.93 & 0.76 & 1.89 & 0.61 & 0.59 \\
\hline & $150 \mathrm{mg} / 1$ & 2.35 & 0.85 & 2.05 & 0.79 & 0.71 \\
\hline L.S.D. 0.0 & & 0.29 & 0.09 & 0.15 & 0.06 & 0.08 \\
\hline \multicolumn{7}{|c|}{$2^{n a}$ Season } \\
\hline \multirow{3}{*}{$15 \mathrm{~cm}$} & $50 \mathrm{mg} / \mathrm{l}$ & 1.56 & 0.64 & 1.50 & 0.36 & 0.44 \\
\hline & $100 \mathrm{mg} / \mathrm{l}$ & 1.88 & 0.68 & 1.56 & 0.44 & 0.50 \\
\hline & $150 \mathrm{mg} / \mathrm{l}$ & 2.00 & 0.76 & 1.68 & 0.52 & 0.56 \\
\hline \multirow{3}{*}{$20 \mathrm{~cm}$} & $50 \mathrm{mg} / \mathrm{l}$ & 1.74 & 0.68 & 1.56 & 0.40 & 0.48 \\
\hline & $100 \mathrm{mg} / \mathrm{l}$ & 1.84 & 0.76 & 1.69 & 0.54 & 0.60 \\
\hline & $150 \mathrm{mg} / \mathrm{l}$ & 2.04 & 0.87 & 1.78 & 0.68 & 0.66 \\
\hline \multirow{3}{*}{$25 \mathrm{~cm}$} & $50 \mathrm{mg} / \mathrm{l}$ & 1.80 & 0.74 & 1.74 & 0.54 & 0.54 \\
\hline & $100 \mathrm{mg} / 1$ & 1.98 & 0.81 & 1.94 & 0.66 & 0.64 \\
\hline & $150 \mathrm{mg} / \mathrm{l}$ & 2.40 & 0.90 & 2.10 & 0.84 & 0.76 \\
\hline \multicolumn{2}{|c|}{ L.S.D. 0.05} & 0.31 & 0.07 & 0.15 & 0.07 & 0.09 \\
\hline
\end{tabular}

TABLE 11. The effect of interaction between plant spacings and mepiquat chloride on leaf photosynthetic pigments concentration (mg/g FW) and seed chemical composition during 2014 and 2015 seasons.

\begin{tabular}{|c|c|c|c|c|c|c|}
\hline \multicolumn{2}{|c|}{ Treatments } & \multirow{2}{*}{$\begin{array}{c}\text { Chlorophyll } \\
\text { (a) }\end{array}$} & \multirow{2}{*}{$\begin{array}{c}\text { Chlorophyll } \\
\text { (b) }\end{array}$} & \multirow{2}{*}{ Carotenoids } & \multirow{2}{*}{ Oil $(\%)$} & \multirow{2}{*}{$\begin{array}{c}\text { Protein } \\
(\%)\end{array}$} \\
\hline \multirow{2}{*}{$\begin{array}{l}\text { Plant } \\
\text { spacings }\end{array}$} & \multirow{2}{*}{$\begin{array}{l}\text { Mepiquat } \\
\text { chloride }\end{array}$} & & & & & \\
\hline & & \multicolumn{5}{|c|}{$\mathbf{1}^{\text {st }}$ Season } \\
\hline \multirow{3}{*}{$15 \mathrm{~cm}$} & $50 \mathrm{mg} / \mathrm{l}$ & 3.69 & 3.21 & 0.23 & 17.51 & 18.59 \\
\hline & $100 \mathrm{mg} / \mathrm{l}$ & 3.73 & 3.55 & 0.31 & 18.23 & 19.66 \\
\hline & $150 \mathrm{mg} / \mathrm{l}$ & 3.87 & 3.99 & 0.39 & 19.94 & 20.13 \\
\hline \multirow{3}{*}{$20 \mathrm{~cm}$} & $50 \mathrm{mg} / 1$ & 3.75 & 3.25 & 0.27 & 18.00 & 19.00 \\
\hline & $100 \mathrm{mg} / \mathrm{l}$ & 3.91 & 3.71 & 0.33 & 19.59 & 20.23 \\
\hline & $150 \mathrm{mg} / \mathrm{l}$ & 4.13 & 3.93 & 0.41 & 20.89 & 22.01 \\
\hline \multirow{3}{*}{$25 \mathrm{~cm}$} & $50 \mathrm{mg} / \mathrm{l}$ & 3.93 & 3.39 & 0.37 & 18.21 & 19.53 \\
\hline & $100 \mathrm{mg} / \mathrm{l}$ & 4.23 & 3.92 & 0.43 & 20.07 & 21.00 \\
\hline & $150 \mathrm{mg} / \mathrm{l}$ & 4.95 & 4.37 & 0.51 & 22.03 & 23.23 \\
\hline \multicolumn{2}{|c|}{ L.S.D. 0.05} & 0.16 & 0.15 & 0.07 & 1.07 & 1.33 \\
\hline \multicolumn{7}{|c|}{$2^{\text {nd }}$ Season } \\
\hline \multirow{3}{*}{$15 \mathrm{~cm}$} & $50 \mathrm{mg} / 1$ & 3.66 & 3.18 & 0.20 & 17.48 & 18.56 \\
\hline & $100 \mathrm{mg} / \mathrm{l}$ & 3.70 & 3.52 & 0.28 & 18.20 & 19.63 \\
\hline & $150 \mathrm{mg} / \mathrm{l}$ & 3.84 & 3.96 & 0.36 & 19.91 & 20.10 \\
\hline \multirow{3}{*}{$20 \mathrm{~cm}$} & $50 \mathrm{mg} / \mathrm{l}$ & 3.72 & 3.22 & 0.24 & 17.97 & 18.97 \\
\hline & $100 \mathrm{mg} / \mathrm{l}$ & 3.88 & 3.68 & 0.30 & 19.56 & 20.20 \\
\hline & $150 \mathrm{mg} / \mathrm{l}$ & 4.10 & 3.90 & 0.38 & 20.86 & 21.98 \\
\hline \multirow{3}{*}{$25 \mathrm{~cm}$} & $50 \mathrm{mg} / \mathrm{l}$ & 3.90 & 3.36 & 0.34 & 18.18 & 19.50 \\
\hline & $100 \mathrm{mg} / \mathrm{l}$ & 4.20 & 3.89 & 0.40 & 20.04 & 20.97 \\
\hline & $150 \mathrm{mg} / \mathrm{l}$ & 4.92 & 4.34 & 0.48 & 22.00 & 23.20 \\
\hline \multicolumn{2}{|c|}{ L.S.D. 0.05} & 0.17 & 0.15 & 0.05 & 1.03 & 1.41 \\
\hline
\end{tabular}

Egypt. J. Agron. 38, No. 1 (2016) 


\section{Fiber properties}

Effect of plant spacings

Fiber properties included length measurements (fiber length and uniformity ratio), fiber bundle tensile properties (fiber strength and elongation) and micronaire reading. Plant spacings had no significant effect on fiber properties in the two seasons (Table 12). Similar results were obtained by Elayan et al. (2008).

TABLE 12. The effect of plant spacings and mepiquat chloride on fiber properties during 2014 and 2015 seasons.

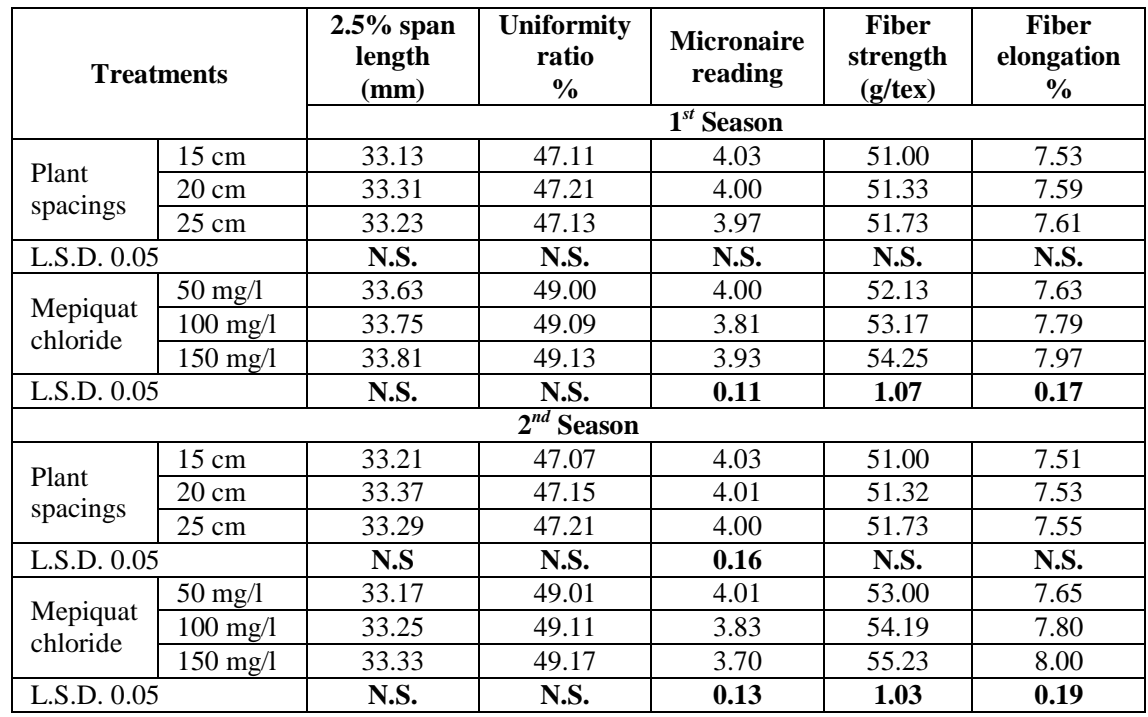

Effect of mepiquat chloride

As shown in Table 12, micronaire reading, fiber strength and elongation\% were significantly affected by application of mepiquat chloride, while fiber length and uniformity ratio were insignificant during the two seasons. The mean values of micronaire reading, fiber strength and elongation\% were increased by the use of the higher MC concentration $(150 \mathrm{mg} / \mathrm{l})$. Similar results were obtained by Sawan et al. (2006).

\section{Effect of the interaction}

Table 13 indicated that each of fiber length, uniformity ratio, micronaire reading, fiber strength and elongation $\%$ were insignificantly affected by the interaction between plant spacings and mepiquat chloride in the both seasons. Similar results were obtained by Nichols et al. (2003). 
TABLE 13. The effect of interaction between plant spacings and mepiquat chloride on fiber properties during 2014 and 2015 seasons.

\begin{tabular}{|c|c|c|c|c|c|c|}
\hline \multicolumn{2}{|c|}{ Treatments } & \multirow{2}{*}{$\begin{array}{c}2.5 \% \text { span } \\
\text { length } \\
(\mathrm{mm})\end{array}$} & \multirow{2}{*}{$\begin{array}{c}\text { Uniformity } \\
\text { ratio } \\
\%\end{array}$} & \multirow{2}{*}{$\begin{array}{c}\text { Micronaire } \\
\text { reading }\end{array}$} & \multirow{2}{*}{$\begin{array}{c}\text { Fiber } \\
\text { strength } \\
(\mathrm{g} / \mathrm{tex})\end{array}$} & \multirow{2}{*}{$\begin{array}{c}\text { Fiber } \\
\text { elongation } \\
\%\end{array}$} \\
\hline \multirow{2}{*}{$\begin{array}{l}\text { Plant } \\
\text { spacings }\end{array}$} & \multirow{2}{*}{$\begin{array}{l}\text { Mepiquat } \\
\text { chloride }\end{array}$} & & & & & \\
\hline & & \multicolumn{5}{|c|}{$\mathbf{1}^{\text {st }}$ Season } \\
\hline \multirow{3}{*}{$15 \mathrm{~cm}$} & $50 \mathrm{mg} / \mathrm{l}$ & 32.55 & 46.13 & 4.03 & 49.88 & 7.33 \\
\hline & $100 \mathrm{mg} / \mathrm{l}$ & 32.61 & 46.23 & 4.03 & 49.91 & 7.52 \\
\hline & $150 \mathrm{mg} / \mathrm{l}$ & 32.70 & 46.55 & 4.01 & 50.00 & 7.63 \\
\hline \multirow{3}{*}{$20 \mathrm{~cm}$} & $50 \mathrm{mg} / 1$ & 32.67 & 46.21 & 4.02 & 50.03 & 7.41 \\
\hline & $100 \mathrm{mg} / \mathrm{l}$ & 32.73 & 46.33 & 4.02 & 50.23 & 7.51 \\
\hline & $150 \mathrm{mg} / \mathrm{l}$ & 32.89 & 46.49 & 4.02 & 50.59 & 7.65 \\
\hline \multirow{3}{*}{$25 \mathrm{~cm}$} & $50 \mathrm{mg} / \mathrm{l}$ & 32.79 & 46.63 & 4.00 & 50.17 & 7.53 \\
\hline & $100 \mathrm{mg} / \mathrm{l}$ & 32.91 & 46.79 & 3.97 & 50.29 & 7.66 \\
\hline & $150 \mathrm{mg} / \mathrm{l}$ & 33.05 & 47.00 & 3.95 & 50.93 & 7.73 \\
\hline \multicolumn{2}{|c|}{ L.S.D. 0.05} & N.S. & N.S. & N.S. & N.S. & N.S. \\
\hline \multicolumn{7}{|c|}{$2^{\text {nd }}$ Season } \\
\hline \multirow{3}{*}{$15 \mathrm{~cm}$} & $50 \mathrm{mg} / \mathrm{l}$ & 33.00 & 47.03 & 4.00 & 50.00 & 7.23 \\
\hline & $100 \mathrm{mg} / \mathrm{l}$ & 33.21 & 47.29 & 4.00 & 50.25 & 7.55 \\
\hline & $150 \mathrm{mg} / \mathrm{l}$ & 33.25 & 46.56 & 4.00 & 50.55 & 7.71 \\
\hline \multirow{3}{*}{$20 \mathrm{~cm}$} & $50 \mathrm{mg} / \mathrm{l}$ & 33.03 & 46.09 & 3.98 & 50.13 & 7.25 \\
\hline & $100 \mathrm{mg} / \mathrm{l}$ & 33.29 & 46.43 & 3.95 & 50.56 & 7.55 \\
\hline & $150 \mathrm{mg} / \mathrm{l}$ & 33.43 & 46.69 & 3.91 & 50.89 & 7.79 \\
\hline \multirow{3}{*}{$25 \mathrm{~cm}$} & $50 \mathrm{mg} / \mathrm{l}$ & 33.17 & 46.25 & 3.89 & 50.56 & 7.29 \\
\hline & $100 \mathrm{mg} / \mathrm{l}$ & 33.59 & 46.73 & 3.87 & 50.91 & 7.63 \\
\hline & $150 \mathrm{mg} / \mathrm{l}$ & 33.61 & 47.05 & 3.75 & 56.03 & 7.77 \\
\hline \multicolumn{2}{|c|}{ L.S.D. 0.05} & N.S. & N.S. & N.S. & N.S. & N.S. \\
\hline
\end{tabular}

\section{Conclusions}

The maximum growth, yield and its components and fiber properties were achieved by using plant spacing $(25 \mathrm{~cm})$ and concentration MC $(150 \mathrm{mg} / \mathrm{l})$ in plants of Giza 90 cultivar. Therefore, the present study strongly suggest the use of such two treatments to improve each of cotton growth and the final yield with good quality as well.

Acknowledgment : Above all, I would like to prostrate for God, who gave patient and made our work successful. The author is grateful for Prof. Dr. A. N. Sharaan professor in Agronomy Department, Faculty of Agriculture, Fayoum University, for his valuable guidance, regarding the revision this paper.

\section{References}

Abdel-Malak, K.K.I., Makram, E.A. and El-Razaz, M.M. (1996) Effect of hill spacing and nitrogen levels in relation to planting dates on growth and yield of Giza 83 cotton cultivar. Assuit Journal of Agricultural Sciences, 27 (1), 155-168.

Ahmed, H.S.A., Zewail, R.M.Y. and Hassan, A.A. (2014) Effect of pix and potassium citrate on growth, productivity fiber quality and yarn on Egyptian cotton. Bull. Fac . Agric. Cairo Univ. 65, 420-430. 
Ali, A., Tahir, M., Ayub, M., Ali, I., Wasaya, A. and Khalid, F. (2009) Studies on the effect of plant spacing on the yield of recently approved varieties of cotton. Pak. J. Life Soc. Sci. 7 (1), 25-30.

Ali, S.A. and El-Sayed, A.E. (2001) Response of cotton cultivar Giza 70 to (Mepiquat Chloride) pix at early and late sowing dates. J. Agric. Sci. Mansoura Univ. 26 (4), 1841-1851.

American Society for Testing Materials (ASTM) (1998a) Standard test method for length and length uniformity of cotton fibers by fibrograph measurement (D1447-89). In : "Annual Book of ASTM Standards", pp. 391-395. Vol. 07.01 ASTM; West Conshohocken, PA.

American Society for Testing Materials (ASTM) (1998b) Standard test method micronaire reading of cotton fibers (D1448-97). In : "Annual Book of ASTM Standards", pp. 396-398. Vol. 07.01. ASTM; West Conshohocken, PA.

American Society for Testing Materials (ASTM) 1998c) Standard test method for breaking strength and elongation of cotton fibers (flat bundle method) (D1445-95). In: "Annual Book of ASTM Standards", pp. 383-390. Vol. 07.01. ASTM; West Conshohocken, PA.

Association of Official Analytical Chemists (AOAC) (1990) "Official Method of Analysis", $15^{\text {th }}$ ed., Inc. USA.

Awan, H., Awan, I, Mansoor, M., Khan, E.A. and Khan, M.A. (2011) Effect of sowing time and plant spacing on fiber quality and seed cotton yield. Sarhad J. Agric. 27 (3), 411-413.

Bednarz, C.W., Shurley, W.D., Anthony, W.S. and Nichols, R.L. (2005) Yield, quality, and profitability of cotton produced at varying plant densities. Agron. J. 97, 235-240.

Boquet, D.J. and Coco, A.B. (1993) Cotton yield and growth interactions among cultivars, row spacing and soil types under two levels of Pix. In : Proc. Beltwide Cotton Conf., New Orleans, LA. $10^{\text {th }}-14^{\text {th }}$ Jan. 1993. Natl .Cotton Counc. Am., Memphis, TN pp. 1370-1372.

Chapman, H.D. and Pratt, P.E. (1961) "Methods of Analysis of Soils, Plants and Waters". University of California, Division of Agricultural Science: Los Angeles, pp: 60-61, 159-179.

Elayan, S.E.D., Abdalah, Amany M. and El-Said, Sawsan A. (2008) Effect of sowing dates and hill spacing on growth, development and some technological properties of some cotton varieties. Egypt. J. Appl. Sci. 23 (3), 83-104.

Elayan, S.E.D., Abdallah, A.M., El-Sayed, M.A. and Abdel-Twab, R.M. (2013) Effect of some growth regulators under different planting dates on growth and yield of cotton. Bull. Fac. Agric., Cairo Univ. 64, 116-128.

El-Hindi, M.H., Said, E.M., Ghonema, M.H. and Khalifa, A.E. (2006) Studies on the effect of some cultural practices on the growth and the yield of Egyptian cotton. $J$. Agric. Sci. Mansoura Univ. 31 (7), 4087- 4095. 
El-Sayed, E.A. (2006) Effect of indol acetic acid (IAA) and mepiqate chloride (PIX) application under different planting date on growth and yield in cotton. Egypt $J$. Agric. Res. 84 (2), 120-113.

El-Shahawy, M.I., El-Gahel, S.M. and Makram, E.A. (1994) Effect of planting dates, hill spacing and nitrogen levels on Giza 76 cotton cultivar. J. Agric. Res. Tanta Univ. 20 (4), 631-642.

El-Shahawy, M.I.M. (1999) Effect of sowing date and pix (Mepiquat Chloride) treatment on growth, earliness and yield of Giza 87 cotton cultivar. Egypt. J. Agric. Res. 77 (2), 829-840.

Emara, M.A., Makram, E.A., Eibagory, Olfat H. and El-Marakby, A.M. (2009) Effect of mepiqate chloride and nitrogen fertilization application time on the Egyptian cotton cultivar Giza 80. Egypt J. Agric. Res. 87 (1), 187-202.

Horneck, D.A. and Miller, R.O. (1998) Determination of total nitrogen in plant tissue. In: "Handbook of Reference Methods for Plant Anal". Library of Congress, USA. pp.75-83.

Horneck, D.A. and Hanson, D. (1998) Determination of potassium and sodium by Flame Emission Spectrophotometer. In: " Handbook of Reference Methods for Plant Anal”. Library of Congress, USA. pp.153-155.

Iqbal, M., Hayat, K. and Islam, N. (2007) Cotton response of mepiquat chloride and nitrogen under ultra-narrow plant spacing. Asian J.Plant Sci. 6 (1), 87-92.

Jat, R.D. and Nanwal, A.K. (2013) Growth, nutrient uptake and profitability of Btcotton (Gossypium hirsutum L.) influenced by spacing and nutrient levels. Crop Res. 45 (1, 2 \& 3), 248-252.

Johnson, R.E. (1967) Comparison of methods for estimating cotton leaf area. Agron. J. 59, 493-494.

Kilmer, V.J. and Alexander, L.T. (1940) Methods of making mechanical analysis of soils. Soil Sci. 68, 15.

Landivar, J.A., Locke, Cespedes, D. Z. and Moseley, D. (1995) The effect of estimated plant concentration of Pix on leaf area expansion and main stem elongation rate. In : Proc. Beltwide Cotton Conf., San Antonio, TX. 4-7 Jan. 1995. Natl. Cotton Counc. Am., Memphis, TN. p. 1335-1338.

Lichtenthaler, H.K. (1987) Chlorophylls and carotenoids : Pigments of photosynthetic biomembranes. Methods Enzymol. 148, 350-82.

Makram, E, A., Abd El-Aal, H.A., Ziadah K.A. and Darwish, A.A. (1994) The interlationship between planting date and each of hill spacing and nitrogen fertilization doses for the Egyptian cotton cultivar Giza 75. Annals Agric. Sci., Ain Shams Univ. Cairo, 39 (2), 609- 622.

Mehasen, S.A.A., Gebaly, Sanaa G. and Seoudi, O.A. (2012) Effectiveness of organic and inorganic fertilization in presence of some growth regulators on productivity and quality of Egyptian cotton. Asian J. Bio. Sci. 5 (4), 171-182.

Egypt. J. Agron. 38, No. 1 (2016) 
Nawaz, H., Hussain, N., Rehmani, M.I.A., Yasmeen, A. and Arif, M. (2016) Comparative performance of cotton cultivars under conventional and ultra-narrow row (UNR) spacing. Pure Appl. Biol. 5 (1), 15-25.

Nichols, S.P., Snipes, C.E. and Jones, M.A. (2003) Evaluation of row spacing and mepiquat chloride in cotton. J.Cotton Sci. 7, 148-155.

Nuti, R.C., Witten, T.K. Jost, P.H. and Cothren, J.T. (2000) Comparisons of Pix Plus and additional foliar Bacillus cereus in cotton. In: Proc. Beltwide Cotton Conf., San Antonio, TX. 4-8 Jan. 2000. Natl. Cotton Counc. Am., Memphis, TN. pp. 684-687.

Sandell, R. (1950) “Colorimetric Determination of Traces of Metal”. $2^{\text {nd }}$ ed. Interscience pub., Inc. New York, USA.

Sarkar, R.K. and Malik, G.C. (2004) Effect of method of planting and crop geometry on productivity of rainfed upland cotton (Gossypium hirsutum L.) grown in low land rice (Oryza sativa) fallows. Ind. J. Agron. 49, 278-281.

Sawan, Z.M., Mahmoud, M.H. and El-Guibali, Amal H. (2006) Response of yield, yield components, and fiber properties of Egyptian cotton (Gossypium barbadense L.) to nitrogen fertilization and foliar-applied potassium and mepiquat chloride. J. Cotton Res. 10, 224-234.

Shekar, K., Ramana, V.M. and Kumari, S.R. (2015) Response of hybrid cotton to chloro mepiquat chloride and detopping under high density planting. J. Cotton Res. Dev. 29 (1) 84-86.

Smith, C.W. (1995) Cotton (Gossypium hirsutum L.). In: "Crop Production, Evolution, History and Technology”. Smith, C.W. (Ed)., pp. 287-349. Johan Wiley and Sons, Inc., New York, USA.

Somro, M.Q., Baloch, G.M., Kaleri, A.N., Ali, S.S. and Chandio, G.M. (2005) Yield response of new cotton variety Shahbaz-95 under different spacing. Indus. Cotton, 2, 136-13.

Steel R.G.D., Torrie, J.H. and Dicky, D.A. (1997) "Principles and Procedures of Statistics. A Biometric Approach". pp.400-428. $3^{\text {rd }}$ ed. McGraw Hill Book International Co., New York.

Texier, P.H. (1993) Le-cotton, cinquieme producteur mondial d huile alimentaire. Cotton Develop. 8, 2-3.

Wang, Z., Yanping, Y. and Xuezhen, S. (1995) The effect of DPC (N,N-dimethyl piperidinium chloride) on the ${ }^{14} \mathrm{CO}_{2}$-assimilation and partitioning of ${ }^{14} \mathrm{C}$ assimilates within the cotton plants interplanted in a wheat stand. Photosynthetica , 31, 197-202.

Zhao, D. and Oosterhuis, D.M. (1999) Physiological, growth and yield responses of cotton to Mepplus and mepiquat chloride. In : Proc. Beltwide Cotton Conf., Orlando, FL. 3-7 Jan. 1999. Natl. Cotton Counc. Am., Memphis, TN. pp. 599-602. 


\section{زاستجابة القطن المصري للمعاملة بالمييكوات كلوريد تحت مسافات}

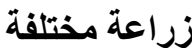

إجريت هذه الدراسة بمحطة البحوث الزر اعية بسدس بمحافظة بني سويف بمصر

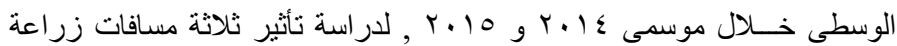

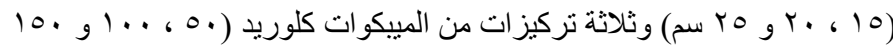

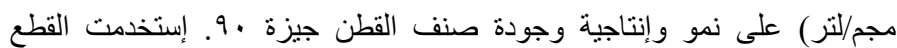

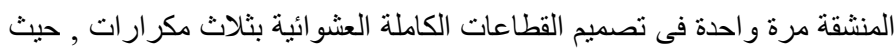

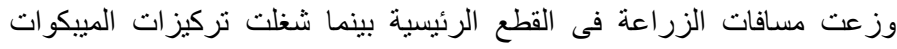

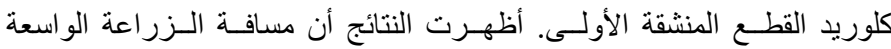

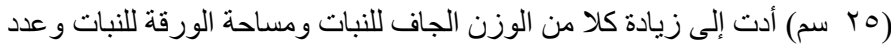

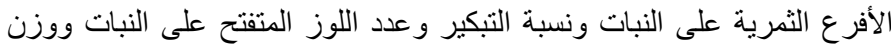

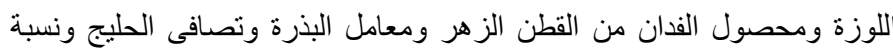

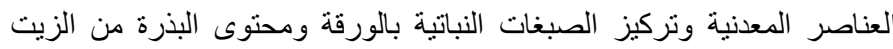

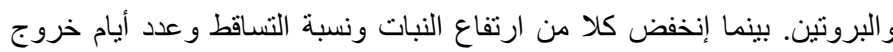

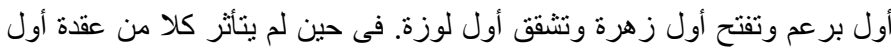

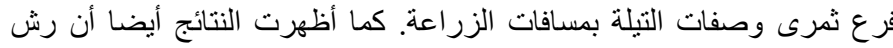

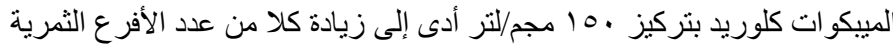

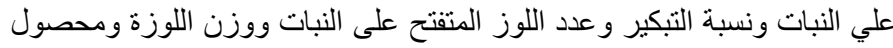

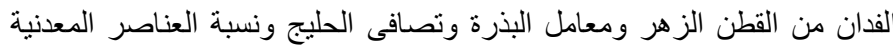

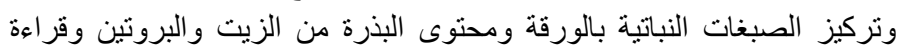

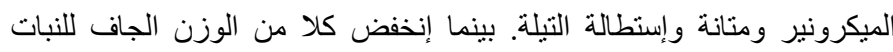

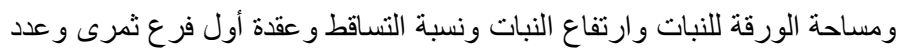

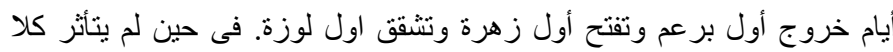

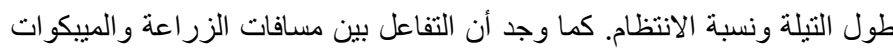

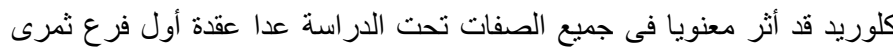

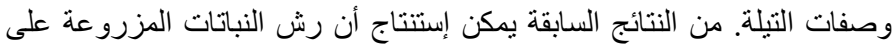

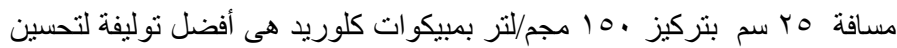
إنتاجية القطن المصرى. 